Studia z Dziejów Rosji i Europy Środkowo-Wschodniej. LI-SI(2)

$\begin{array}{llllllllll}\mathrm{M} & \mathbf{A} & \mathrm{T} & \mathrm{E} & \mathrm{R} & \mathrm{I} & \bar{A} & \mathrm{~L} & \mathrm{~S}\end{array}$

Dariusz Miszewski

War Studies University in Warsaw

\title{
Polish foreign policy and role of the armed forces in geopolitical considerations of Lieutenant Colonel Tadeusz Zakrzewski addressed to Prime Minister Władysław Sikorski
}

Outline of contents: In January 1943, Commander-in-Chief and Prime Minister of Poland, General Władysław Sikorski, received a memorandum on the objectives of the Polish foreign policy drawn up by Lieutenant Colonel Tadeusz Zakrzewski (1897-1964). Zakrzewski believed that, to ensure Poland's victory in the war, the government should make use of its three main advantages with regard to the governments of the Allied states, the European allies of Germany and international public opinion. The role of the armed forces was to fight alongside their allies. The nation was expected to mount an active resistance against the Germans and to combat collaboration with the occupier. The task of propaganda was to spread knowledge about the Polish contributions to the war, as well as to present the Polish proposal for the framework for peace. The expected outcome of these policies was the permanent restoration of the Polish state within its pre-war borders - with some territorial gains at the expense of Germany - and the establishment of the Union of Central Europe.

Keywords: World War II, Polish-Soviet relations, Central Europe, Polish Government-in-exile, Polish Army

On 25 January 1943, Lieutenant Colonel Tadeusz Zakrzewski submitted a formal letter to Colonel Stanisław Gano, Head of the $2^{\text {nd }}$ Department of the Staff of the Commander-in-Chief. The letter contained a geopolitical analysis of the Polish foreign policy and of the role of the Polish Armed Forces during the Second World War. Zakrzewski wished to share his personal reflections with the Commander-inChief and Prime Minister of Poland - General Władysław Sikorski - and the Polish Foreign Minister. He believed that, as a senior officer and citizen, he had the right, if not the duty, to express his opinion on the current international situation, and to suggest some solutions for the country. Zakrzewski argued that his interest 
in Poland's activity on the international scene did not constitute involvement in politics, as he did not intend to criticise the Polish authorities. He emphasised that he pursued his interests in his free time (as $2^{\text {nd }}$ group officer), so as not to neglect his daily military duties. Zakrzewski's remarks on Poland's military and political situation transmitted to the military authorities in London were perceived as "an act of disloyalty" by some officers of the Polish Armed Forces in the East. ${ }^{1}$

Between 1938 and 1940, Lieutenant Colonel T. Zakrzewski (1893-1966) acted as military attaché in Bucharest. ${ }^{2}$ Before that, he served in the General Staff of the Polish Armed Forces (2nd Department). In September 1939, he renounced obedience to the Commander-in-Chief, Marshal Edward Rydz-Śmigły, and to the Chief of the General Staff, General Wacław Stachiewicz. ${ }^{3}$ Alongside ambassador Roger Raczyński and councellor Alfred Poniński, he supported the actions of General Sikorski, who arrived in Romania in mid-September, wishing to remove the Sanation from power. ${ }^{4}$ In consultation with the French Embassy in Bucharest, Zakrzewski arranged the appointment of new Polish authorities in France in order to pursue the fight against Poland's occupiers. ${ }^{5} \mathrm{He}$ conducted the political verification

1 The Polish Institute and Sikorski Museum in London (IPMS), no. PRM112/1, Pismo ppłk. T. Zakrzewskiego do Szefa Oddziatu II Sztabu Naczelnego Wodza w Londynie, Jerusalem, 25 January 1943, p. 46.

${ }^{2}$ H. Bułhak, "Próba czechosłowackich kół wojskowych nawiązania rozmów sojuszniczych z polskim Sztabem Głównym w marcu 1938 r.”, Studia z Dziejów ZSRR i Europy Środkowej, 15 (1979), pp. 205-209. Following the seizure of Austria by Germany, the Czechoslovak military attaché in Bucharest, Lieutenant Colonel Otokar Buda, contacted Zakrzewski to propose that the military authorities of both states negotiate a military alliance. Buda believed that the solution the most profitable - in terms of politics, economy and security - to stop Germany would be a state union of Poland and Czechoslovakia, which complemented each other. Their potential would allow them to spread their influence onto the Baltic, Black and Mediterranean Seas. At the request of Marshal Rydz-Śmigły, General Stachiewicz, Chief of the General Staff, forbade T. Zakrzewski from pursuing relations with Buda, much to the resentment of the latter; Historia Dyplomacji Polskiej, vol. 4: 1918-1939, ed. P. Łossowski, Warszawa, 1995, p. 54.

3 W. Pobóg-Malinowski, Najnowsza historia polityczna Polski (okres 1939-1945), vol. 1, Gdańsk, 1990, pp. 78-81.

4 A. Poniński, "Wrzesień 1939 r. w Rumunii”, Zeszyty Historyczne, 6 (1964), pp. 152-154, 178-180, 197-198. A. Poniński mentioned that it was T. Zakrzewski who executed the personal orders of General Sikorski in Romania, rather than ambassador R. Raczyński and himself. He described T. Zakrzewski as an ambitious and capable officer, who wanted to play a significant role alongside Sikorski, zealously carrying out his recommendations regarding civilians and military personnel deemed unwelcome in France; T. Katelbach, "Akt pierwszy dramatu", Zeszyty Historyczne, 7 (1965), p. 52; M. Dymarski, Stosunki wewnętrzne wśród polskiego wychodźstwa politycznego i wojskowego we Francji i Wielkiej Brytanii 1939-1945, Wrocław, 1999, pp. 31-35, 70.

${ }^{5}$ Historia Dyplomacji Polskiej, vol. 5: 1939-1945, ed. W. Michowicz, Warszawa, 1999, pp. 130-131; T. Dubicki, S.J. Rostworowski, Sanatorzy kontra Sikorszczycy, czyli walka o władzę na uchodźstwie w Rumunii 1939-1940, Warszawa, 1993, pp. 23, 62, 136-137; T. Dubicki, Wojsko Polskie w Rumunii w latach 1939-1941, Warszawa, 1994, pp. 42-55. Dubicki disconfirms the existence of a conspiracy, the opposition having achieved the removal of the Sanation from power merely by taking advantage of the international situation and the position of the Polish authorities in Romania. 
of Polish civil and military émigrés in Romania in terms of their usefulness in supporting General Sikorski's cause. ${ }^{6}$ Following the dissolution of the Polish Embassy in Romania in 1940, he relocated to the Middle East to join the Independent Carpathian Rifle Brigade. ${ }^{7}$ He ended up in the officers' reserve, remaining at the disposal of the Commander of the Polish Armed Forces in the Middle East. On the latter's orders, he was placed in 1942 on a three-year leave. Commander-inChief Sikorski returned him to active duty on 1 June 1943. The two met in Cairo, during Sikorski's inspection of the troops in the Middle East. The general promised Zakrzewski a position in London as soon as he would return to Great Britain. Sikorski's death in July 1943 resulted in Zakrzewski being transferred to the officers' reserve of the Commander-in-Chief, General Kazimierz Sosnkowski. At his own request, he underwent a Silent Unseen (Cichociemni) training in London, but was not parachuted into Poland. Zakrzewski returned to Poland in November 1945. He occupied a managerial role at the organisational department of the Central Executive Committee of the Polish Socialist Party (PPS); he belonged to a group that opposed the merger with the Polish Workers' Party (PPR). In December 1954, he was arrested on charges of collaboration with the 2 nd Department of the General Staff. He was rehabilitated upon his release in the spring of 1955, and assumed the position of director of the State Enterprise for Sporting Events.

In his letter, Zakrzewski asserted that the key to Poland's victory was a properly enforced foreign policy, implemented with the support of the Polish Armed Forces, the Polish populace, and propaganda. The role of the armed forces was to fight alongside their allies. The nation was expected to mount an active resistance against the occupier. The task of Polish propaganda was to oppose their German counterpart, to weaken the will of smaller states and nations to fight alongside the Germans, and to support the principles and strategic goals of the Allied states. Zakrzewski emphasised that Poland would only achieve true victory with the consolidation of its independent existence, the demarcation of safe borders, and the adoption of a political order in Central and Eastern Europe that would strengthen Poland's independence and ensure constant progress. To this end, the Polish foreign policy should attempt to correlate the interests of other states - especially those mutually contradictory - with Poland's cause. The calculated

${ }^{6}$ J. Kowalewski, "Cykl rumuński”, Zeszyty Historyczne, 6 (1964), pp. 137-138; T. Katelbach, "Akt pierwszy dramatu”, Zeszyty Historyczne, 7 (1965), p. 67; W. Pobóg-Malinowski, "Na rumuńskim rozdrożu (fragmenty wspomnień)", part 3, Kultura, 9-10 (1948), pp. 136-137, 159-160. T. Zakrzewski and A. Poniński carried out the verification of the Polish émigrés in Romania at the behest of W. Sikorski.

7 T. Dubicki, A. Suchcitz, Oficerowie wywiadu WP i PSZ w latach 1939-1945, vol. 1, Warszawa, 2009, pp. 322-326. While in Romania, T. Zakrzewski set up the so-called Guerrilla Division, responsible for sabotage activities in Romania in support of the Allied troops heading from the Balkans toward Poland. He also organised a propaganda diversion unit with the aim to turn Germany and the USSR against each other. Following the 1940 evacuation to Turkey, this unit was taken over by the British. 
expressions of appreciation of Poland's military exploits should have no importance in the assessment of the accomplishment of its wartime goals.

The western border that T. Zakrzewski considered safe and acceptable for the Allied powers encompassed Opole Silesia, while East Prussia was to function as an autonomous duchy or a federal republic alongside Poland. Admittedly, both these provinces were mostly inhabited by Germans, but they were indispensable to Poland for economic reasons, and they played a key role for the country's security and that of the whole continent. He found it hard to imagine that the European democracies agree to a mass expulsion of the German population from the territories transferred to Poland after the war. In order to neutralise the Soviet claims to the Polish Eastern Lands, he suggested entering a union with Lithuania, even at the price of ceding Wilno back, while Eastern Lesser Poland, Bukovina and Carpathian Ruthenia would form the pro-Polish republic of Western Ukraine. The cultural division of Ukrainian lands between Poland and the USSR would guarantee a permanent separation of pro-Western Ukrainians from their Eastern counterparts, undermining their irredentism. Finally, Poland would engage in a close political and economic union with Czechoslovakia, Hungary, Yugoslavia, Greece, and possibly Romania, in order to increase the economic potential of Central Europe, as well as the region's security against Germany.

In return for the Soviet approval of the Union of Central Europe and the modified western border, Poland would sign a treaty of mutual security with the Soviet Union. Poland would consent to the incorporation of Finland, Latvia, Estonia, Bessarabia and Dobruja by the USSR, while Romania and Bulgaria were to become dependent countries, which would ensure the Soviets' strategic security on the Baltic and Black Seas. Should the Soviet Union settle for control over Bulgaria alone, and Romania enter the Union of Central Europe, a Romanian-Hungarian union would be required to reconcile them over Transylvania. As regards the Far East, Poland would support the annexation of Manchukuo by the Soviet Union, or its partition with China and the return to the 1905 Soviet-Japanese border, which would push the USSR towards to the Pacific Ocean. Basically, Zakrzewski's concept relied on the division of spheres of influence in Central and Eastern Europe between Poland and the Soviet Union.

As regards Great Britain, Poland would propose a political, economic and military alliance. Both countries would oversee the peace treaty signed by Germany. The renewed alliance with France would also be of an anti-German nature. The United States would receive Poland's support in the implementation of their foreign policies, and in their efforts towards the establishment of global peace and a worldwide security system. On account of its wartime merits, Poland would be allowed to participate actively in the elaboration of a post-war order that would ensure the protection of Polish interests, with the Atlantic Charter as its foundation. The international system of peace and security should guarantee the freedom, prosperity, security and development of all humans, states and nations. 
The post-war governments should all adopt democracy to guarantee freedom and eliminate the concept of war from international relations. T. Zakrzewski tolerated the use of force in defence of freedom and democracy, but only in accordance with international law. National minorities would obtain civil rights equal to those of the ruling nation, the unhampered freedom of national and cultural development, and broad self-governance; the minorities living in a compact area of a given state would be granted autonomy. The occurrence of population exchanges was not excluded, on condition that they would be truly voluntary and that the protection of property would be guaranteed by international agreements.

Zakrzewski divided Europe on political, economic, historical and cultural grounds into eight regional unions: 1. Union of Central Europe, led by Poland; 2. Northern Union: Sweden, Norway, possibly the Netherlands; 3. Eastern Union: Finland, Latvia, Estonia, Bulgaria and possibly Romania, led by the USSR; 4. Union of German Nations: Germany and Austria; 5. Union of the French Empire with Belgium and the Netherlands (could be merged with Great Britain); 6. Italian Union: Italy and its colonies excluding Abyssinia (Switzerland in the French or Italian Union; Albania in the Central or Italian Union); 7. Iberian Union: Spain, Portugal, and their colonies; 8. Great Britain and its empire. The colonies of the European countries would be transformed into federal states after the war. The United States would cooperate closely with the rest of the American countries.

In order to ensure the economic development of the world, the different states should open up to trade and to the flow of people, but with international capital always under control of the national authorities. The countries all over the world should open their markets by means of organising into large economic areas, where tariffs would be gradually abolished. However, the federations should not limit the sovereignty of their members excessively. The dominance of any member state would therefore be excluded. In order to increase political and economic security in the world, the superpowers and developed countries should assume responsibility for the development of backward countries and nations in Africa and Asia. The harmonious prosperity of the world would be overseen by international organisations that would be responsible for the protection of minority rights, free trade of commodities and raw materials, and migration flows of the world's population.

After the war, the Axis countries would be disarmed, and their security ensured by their direct neighbours, bound by alliance with the Western Powers. The Union of Central Europe and the United Kingdom would assume responsibility for Germany, while France would oversee Italy. The disarmament and control over the Axis states could not engender any restrictions of their internal sovereignty, nor should they become dominated by their neighbours. The international security structures would react too slowly to assume sole responsibility for world peace and security. Hence, security in Europe would be ensured by local superpowers and regional federations, while the United States would act as global peacekeeper with the support of their wartime allies. 
Zakrzewski advocated that the Polish concepts for European order and world peace be promoted by the government and its institutions with no regard for material costs, with the help of organised groups of Polish civilian refugees. Polish propaganda should be directed mainly at different national authorities and the international public opinion. The task of the Polish government should be to create propaganda centres in every country of significance and to exert influence on their elites.

Zakrzewski's reflections and ideas expressed in January 1943 corresponded with the political plans of Prime Minister Sikorski. During the Second World War, the general had come forward with the idea of a Central European federation built around the Polish-Czechoslovak alliance, and implemented with the support of Great Britain and the United States. He believed Poland's security could be guaranteed by means of shortening its borders with Germany (Opole Silesia, East Prussia and the Free City of Gdańsk) and merging the countries located between the USSR and Germany into one organism with common foreign, military and economic policies. The Central European federation would bring together all those countries whose Western allies failed to defend back in 1938-39. As a significant centre of political, economic and military force, the federation was supposed to ensure the equilibrium of power in Europe. Unlike the concept of Marshal Józef Piłsudski and his sympathisers, Sikorski's united Central Europe would not constitute an independent superpower or a Third Europe, but rather a peaceful structure, fully integrated with Western Europe. The Central European federation would not have an anti-Soviet character (isolation or hostility towards the USSR). The relations with pro-Soviet Czechoslovakia were supposed to guarantee Moscow's approval. General Sikorski based his cooperation with the USSR on the Sikorski-Mayski Treaty and the Moscow Declaration of 1941, i.e. on the principles of territorial integrity, respect of independence and sovereignty, and non-interference in internal affairs. He did not raise the matters of Belarus and Ukraine on the international stage. On the other hand, he insisted on the independence of Lithuania and its relationship with Poland. In the interest of maintaining good relations with the Soviet Union, he was ready to recognise its influence over the two independent Baltic states, Latvia and Estonia.

Zakrzewski's analysis from January 1943 ceased to be valid after the Red Army's victory at Stalingrad in February. From this moment, it became clear that the USSR would act as a deciding force with regard to the political order in Central Europe. One fact worth mentioning is that in January 1944, Zakrzewski also prepared a geopolitical analysis of Poland's international situation for Prime Minister Stanisław Mikołajczyk. ${ }^{8}$

${ }^{8}$ D. Miszewski, "Memoriał o podziale stref wpływów w Europie Środkowo-Wschodniej pomiędzy Polskę a Związek Radziecki, napisany przez podpułkownika dyplomowanego Tadeusza Zakrzewskiego, przeznaczony dla premiera Stanisława Mikołajczyka", Studia z Dziejów Rosji i Europy Srodkowo-Wschodniej, 40 (2005), pp. 285-294. 
Lieutenant Colonel Tadeusz Zakrzewski, Jerusalem, 25 I 1943

"My view on Poland's foreign policy and the role of the armed forces"

I. In the current circumstances, the only key factor for Poland to win the war is a proper foreign policy. The sources of strength, on which this policy must be founded, are: 1. The state's formal position, 2. The efforts of the Polish Armed Forces, and 3. Active participation in the war by means of our political activity, propaganda, and military technology.

The only political instrument at our disposal are the activities of our government - the Prime Minister, the Foreign Minister and Minister of Propaganda in particular.

Ad 1. The duty of our country is clear; it is under occupation, and as such, it has to prove its unwavering will to fight for the integrity and independence of Poland through its attitude and behaviour. So far, the country has been performing this task superbly.

Ad 2. The role of the Polish Armed Forces in exile is not limited to being the embodiment of Fighting Poland; above all, they must provide political capital for the government's policies. They provide it by fighting. Therefore, they should keep doing so. In order for this capital to last until the end of the war, it should not be spent at once, but moderately, thus permanently. The Polish soldier must fight, prevail and die; his death legitimises the politicians' efforts toward the restoration of the Polish state. He should exclude the possibility of a safe and peaceful return to his homeland. He may count on his wartime luck, but he must, above all, desire to fight the enemy. And finally, the Polish soldiers must be the heroes of their own epic that will later serve to educate the future generations of Poles and the future Polish Army. Therefore, they must always prove the highest levels of morale and experience.

Ad 3. In order to increase our value as allies, our participation in the war should also involve combating the enemy on political grounds - in the field of propaganda in particular. What I mean is that our political activity can effectively complement the accomplishment of strategic goals by our allies. For instance, from the perspective of political strategy, we should currently focus on: Turkey, Spain, Portugal, France, Argentina.

Our propaganda, especially the diversionary kind, may be much more effective than our Allied counterparts against small Axis nations, and thus weaken their will to fight and complicate the mutual relations between Axis states. We can also take active part in diversionary propaganda in Italy.

Since we do not have a large army, we do not require operational studies units of our own. On the other hand, with our many officers, we can perform studies for the Allied armies, either in cooperation with them at their headquarters, either individually, but for their benefit. I believe that we could fare just as well 
as our foreign counterparts; in modern war, where new concepts dominate every operation, we could prove ourselves very useful.

II. What policy should we adopt in order for Poland to prevail?

To answer this question, we must first define our political goals, which will, in fact, be tantamount to our victory. First and foremost, we must determine: what does winning the war mean? In my opinion, winning the war means reaching a point where Poland could once and for all establish itself as an independent power, rather than a seasonal state existing from war to war. In order to achieve this, we must realise our goals with regard to our national borders and to achieving such a situation in our region (and beyond) that would prove the most favourable to our existence.

Our political goals must be real, i.e. they should be ambitious, but not Romantic. In general, Romantic politics may only be valid if implemented in long term. At times of war, however, the political aspects should not be taken into account; nor should historical ones once the peace treaty is signed. The war could go on for years, or it may just as well come to an end soon and abruptly. We will not solve all our issues at once during the war. Let us leave some for times of peace.

And finally, we must choose what grounds to pursue our policies on in order to achieve actual results, instead of getting lost in the realm of appearances, fiction, and trivial issues. The Polish foreign policy should, especially now, consist in correlating skilfully the interests of other states - especially those mutually contradictory - with Poland's cause. In other words, our political strategy should not consist in expressing our rights, but rather in enticing other states and nations to settle our issues in a way we find favourable. Recent events have undeniably proven that common interests, rather than mutual sympathies, define and consolidate the stances of countries on the international scene. Sympathies are valuable merely as short-lived assets. Besides, sympathies are subject to frequent and rapid fluctuations depending on the material situation.

III. What should our real political goal be?

Poland's borders:

A) Western: as before, with slight changes in Silesia (part or entirety of Opole Silesia to Poland).

B) Eastern: as before.

C) East Prussia incorporated into Poland as an autonomous duchy or a republic.

D) Lithuania bound by union with Poland.

E) Poland in a more or less close economic and political alliance with the independent Czechoslovakia, Hungary, Yugoslavia, Greece, and possibly Romania.

What is the feasibility of this goal founded on? It lies not so much in the reasonableness of its legal, economic and military premises, but rather in the fact that our goal corresponds to the resultant of various interests of other states, which we now must agilely secure with our influence. 
Ad a) Annexing territories with a sizeable Polish population will cause no difficulties, as it will be a natural consequence of Germany's defeat. We cannot expect, however, left-wing democratic governments with a very liberal, often revolutionary attitude, to approve the annexation, without no obvious reason, of territories inhabited by a German majority. This would be in contradiction with their ideologies, and negate the whole meaning of the current war.

Ad b) The eastern border can be defended, not only by means of formal insistence on the treaties already in force, but also with a certain scheme. Formal positions are usually unconvincing and seldom effective in times of war or revolution, since both war and revolution are meant to suppress all forms and make room for new ones. In regard to this matter, I would suggest the following solution that the Soviets will find difficult to oppose: 1 . The matters of the north-eastern border and the union with Lithuania should be treated as one. The union with Lithuania solves the issue of the north-eastern border, even at the cost of ceding Wilno; 2 . The south-eastern border should be defended by means of creating the autonomous republic Western Ukraine incorporated into Poland. Consequently, it would be appropriate to claim Bukovina and Carpathian Ruthenia as an expression of the unification of all Western Ukrainians, so different in their culture and customs from the Eastern Ukrainians. We might obtain support in this matter from Western and Balkan states. The Soviets would receive compensation (detailed further).

Ad c) East Prussia can only be annexed for economic reasons or with regard to the security of Europe and Poland. This said, Poland could benefit from access to the coast and from the East Prussian soil, Europe would then benefit from increasing its economic equilibrium by strengthening Poland, and East Prussia would see its wellbeing improve owing to reliance on Poland. In terms of security, this would eliminate the remnants of "Drang nach Osten" and diminish Poland's sense of threat posed by the proximity of German territory. However, in order to counter all allegations of unlawful claiming of territories inhabited for the most part by Germans, East Prussia should be incorporated as a duchy or as an autonomous, if not federated republic (as in the case of Soviet republics). The question of the resettlement of Germans from East Prussia should not be raised, as this would conflict with the general objectives of the war, namely the protection of freedom and citizens' rights; this would even resemble the totalitarian methods actually combated by our democratic camp.

Ad d) Besides invoking historical laws, the union with Lithuania can be defended by accentuating its beneficial aspect in terms of economy and security for Poland, Lithuania, their allies, and the entire world alike. I believe that we can obtain the support of the Western countries and the US, as well as the consent of the Soviets, and even that of the defeated states.

Ad e) The political and economic union with Czechoslovakia, Hungary, Yugoslavia, Greece, and possibly Romania, can be justified by its importance in terms of economy and security, especially if depicted as a condition for the proper 
reconstruction of the post-war world. Obtaining consent from all our allies and the Soviets should be feasible.

All these goals, however, can only be achieved at the cost of some compensation to the interested parties. I would consider the following:

A. What we can offer Russia: 1) eternal peace, defence from the West; 2) consent for the incorporation of the Finnish, Latvian and Estonian Republics into the Soviet system, which will provide Russia with proper presence on the Baltic Sea; C) consent for the transfer of Bessarabia and parts of Dobruja to the Soviets, and ultimately even for the incorporation of Romania and Bulgaria into the Soviet system as federal states. The entrustment of the USSR with providing security for these states. This will ensure the Soviet domination on the Black Sea and in the Danube Delta; 4) support for the placement of Manchukuo under Soviet control, or the partition of Manchukuo between China and the USSR, meaning the borders would be reverted to their pre-1905 state. This would provide the Soviets with access to the Pacific. Currently Vladivostok is constantly at risk and communication is hindered; 5) favourable trade agreements and political/economic cooperation.

We should use Russia mainly to defend our demands concerning the western border, the incorporation of East Prussia and the planned federation with our neighbours.

B. What we can offer Great Britain: 1) supervision of Germany by means of a strong military. Entrusting us with this task would be convenient for England, as France should rather keep an eye on the Italians, who constitute a constant threat; 2) conclusion of the defence pact of the British Empire in its post-war form; 3) favourable trade deals and political/economic cooperation.

C. What we can offer the US: 1) support in designing the world in line with the objectives of US economic policy; 2) assistance in the organisation of security; 3) our role as balance factor between the Soviets, England and France; 4) our role as warrantors of American property.

D. What we can promise France: 1) to defend its empire; 2) to support its appointment as supervisor of Italy and Spain; 3) to support it in Mediterranean matters.

By playing on the interests of individual states, we may ultimately become the decisive factor. If we succeed, even the defeated states will support our interests. Germany and Hungary, for instance, may be interested in solving the issue of our eastern border.

However, for such a political game to prove successful:

1. We must assume in our approach to any talks - whether overt or secret, full or gradual, straight or cautious - that Poland intends to act as protector of the post-war order in terms of the security and freedom of all countries and nations. We shall always oppose the aggressors.

2. We must play this game on the grounds of an appealing, dynamic and creative concept, aimed at the well-being of the international community and mankind, 
i.e. a concept that will meet no opposition neither now, nor during peace talks. In other words, we must offer the most comprehensive and captivating picture possible of the future of the world, and gain supporters in all countries that will join us in our vision, and thus will fight for our cause, perhaps even without knowing it.

It should be stated that the all declarations made so far with reference to the organisation of the post-war world, including the Atlantic Charter, remain very vague to this day.

IV. What concept of the post-war order should we adopt?

Taking into account the evolution of notions, their shift towards the left, we must adopt a radical approach. For tactical reasons, we should build on the premises of the Atlantic Charter and develop it further in the following direction:

1. The future world must be designed so as to guarantee the inseparable rights of humans, nations and states to: a) freedom, b) well-being, c) security, d) progress.

What do I mean by "freedom"? Complete freedom comprises the freedom of the human being, the nation and the state - all inseparable.

The freedom of man is expressed in: 1 . the freedom of thought, speech and deed (without prejudice to the dignity of other people and the well-being of the community); 2. the right of input into the governing process (the ability to elect authorities and to participate in the governing).

The freedom of the nation includes: 1. the opportunity of cultural and economic development in accordance with national traditions; 2 . assured participation in the life of the state.

Nations that cannot constitute a separate state or a separate body, whether for economic, or any other reasons, shall benefit from the full rights of the citizens of their state, including far-reaching self-governance and autonomy, as well as the absolute freedom in cultivating national traditions and culture.

The freedom of the state lies in its right to: 1 . shape its reality according to its own will. 2. exert external influence. 3. benefit, without sacrifices being made, from natural resources (raw materials) that said state does not possess within its own territory.

What do I mean by "well-being"?

1. The well-being of the citizen: the opportunity to work for appropriate wage (in accordance with the cultural needs of the person).

2. The well-being of the state: the opportunity to provide the citizens with the above-mentioned conditions, and the possession of resources allowing progress.

What do I mean by "security"?

1. All great nations and small ones alike, the entire mankind must finally have the certainty that no cliques of madmen will ever come to power again to push the nations towards mutual destruction.

2. All people and nations should live under the belief of being safe, and that all possible enthusiasts of violence will be immediately pacified, even before they commit any wrong. 
3. The issue of security is not confined to protection from military aggression, but from speculative attacks as well.

What do I mean by "progress"?

1. We follow the Christian teachings on the calling of man and his commitment to attaining the divine ideal, thus we strive for intellectual progress (of thought and ethics) and material progress (the understanding and mastery of nature) alike.

2. The accomplishment - by all people, states and nations - of their duty toward the international community and humanity as a whole.

The implementation of these concepts must be founded on a proper peace pact, allowing the appropriate reconstruction of the world.

\section{What should the premises of this peace pact be?}

A. In order to ensure freedom, democracy must reign supreme absolutely everywhere. The establishment and preservation of democracy shall be a condition for peace, and the preservation of the democratic systems should be protected by an international body created for this purpose. As a universal value, the democratic systems must be protected even by force, if necessary.

B. Well-being can be achieved by creating suitable economic conditions for the state, i.e. conditions, where the citizens can truly live in prosperity. The conditions necessary: a) the creation of economic bodies, whose conditions would allow far-reaching self-sufficiency. Only large bodies can guarantee this; many customs barriers must therefore disappear. The creation of large and most self-sufficient bodies possible should constitute an introduction and a starting point for the economic reconstruction of the world. This may take place by means of forming federations of free nations as large economic and political bodies without prejudice to their individual freedoms, and without the preponderance of one nation over the others (the free with the free, the equal with the equal); b) depriving capital of its power and dictatorial traits, and subordinating it to the needs of the population.

My solution for Europe is the following: 1. The Union of Central Europe composed of Poland, Lithuania, Czechoslovakia, Hungary, Yugoslavia, Greece, and possibly Romania (although Romanian petroleum is valuable, access to the Adriatic is more important, and we will not obtain it without the consent of the Soviets). Romania should be the subject of negotiations and political rivalry. Depending on the situation, we should either get it to our side, or cede it to the Soviets in exchange for a large sum. If Romania were to side with the Union of Central Europe, the Hungarian-Romanian issue should be resolved by a union of these two states.

2. Eastern Union: Russia, Finland, Latvia, Estonia, Manchukuo, Bulgaria, and possibly Romania (Romania as compensation for Russia for the approval of the Union of Central Europe).

3. Union of German Nations: present-day Germany without East Prussia, Austria, Istria with Trieste (Yugoslavia would obtain Fiume). 
4. Union of the French Empire: France and its former colonies, as federal states, and possibly in an alliance with Belgium.

5. Northern Union: Sweden, Norway, possibly the Netherlands.

6. Iberian Union: Spain and Portugal with their colonies as federal states.

7. Italian Union: Italy with its former colonies transformed into Arab republics, bar Abyssinia.

8. United Kingdom and

9. United States of North America would remain unchanged, as economic bodies that could constitute a role model for the new federations.

Switzerland, Belgium, the Netherlands and Albania could choose which federation to join; for instance, Switzerland may join either the Union of the French Empire, the Italian Union, or the German Nations.

Belgium and the Netherlands may belong either to the Union of the French Empire, to the United Kingdom, or to the Northern Union.

Note: As regards the United States and the United Kingdom, as well as the matters of other countries, it would be preferable not to express any opinions nor interfere, focusing instead on enforcing the principles.

C. Security. We shall ensure security by means of: 1 . the disarmament of the warmongering nations; 2 . a unilateral guarantee that the provisions on disarmament will be implemented. These guarantees will be obtained by delegating the supervision of the implementation of the treaties to the nations most interested, and to those who can warrant that they will respect these agreements, avoid abusing their privileges, and exercise their powers loyally, by virtue of their centuries-old tradition, their reputation, and their policies; 3. a collective guarantee system.

Ad 1. The disarmament should apply to the Axis states, i.e. Germany, Italy, Hungary, Rumania, Japan, and Siam. These countries should be fully disarmed. The disarmed countries would incur the same security costs as their protectors. Once they join a certain political and economic system, they may participate in the matters of security only financially.

Ad 2. In practice, I imagine it the following way: a) Germany's security and non-violation of the terms of the peace treaty supervised by the Union of Central Europe, led by Poland; b) Italy's security and non-violation of the terms of the peace treaty supervised by France; c) security in Africa supervised by the British Empire and the United States; d) security in South America supervised by the United States and several South American states; e) security in Asia and the Pacific states supervised by Russia, the United States, Great Britain and China.

In each case, security can be enforced by different means and methods, depending on the conditions.

In order to avoid abuses of power by the protecting states: said state must be responsible before the international community for all actions with regard to the protected country. A collective guarantee must be in force. When signing the 
peace treaty, all countries oblige themselves to fulfil the provisions of the peace treaty, and, in the event of a breach, to defend the aggrieved party.

Ad 3. Collective and mutual guarantees should function as an auxiliary instrument, but they are insufficient on their own, as they are enforced far too slowly. The protection of security by an international force may be possible, but it will be marred by a very slow pace of reaction. Moreover, as an organisation comprising individuals from different nations, the international force may lack a sufficient moral bond, and therefore sufficient power to perform its duty at the decisive moment.

Security should be universal, which means it should apply equally to the disarmed and the victorious countries. It should be considered a common good. The protecting states shall defend the existing state of affairs in the country whose security they have been entrusted with in any case, irrespective of what direction the threat may be coming from. In other words, should we become responsible for Germany's security, our duty would not only involve detecting any infringements of the provisions of the treaty, but also preventing third parties from interfering with the existing state of affairs or exploiting Germany's lack of defence power.

D. Progress. Freedom is the foundation of progress, but we should nonetheless enable and inspire the different nations and individuals to strive for perfection: a) individuals: on ethical, moral and material grounds, b) states and nations: in terms of organisation of their political and economic conditions.

The way I see it:

1) There should be no people in the world below a certain cultural level. As long as there still are some, we must support them.

2) The cleansing of ethics - from excessive nationalist and totalitarian influences in particular - and its improvement among both the uninformed masses and the intelligentsia.

3) The encouragement of all nations, including those currently in a wild, uncivilised state, to live and participate in the efforts toward the well-being of the entire humanity.

4) The acquisition of new goods by uncovering the secrets of nature, exploiting the barrens and investigating the unexplored fields.

5) Perpetual sustaining of the initiative.

Every nation and state should have its own mission to accomplish. For instance, Poland could be entrusted with transforming Rhodesia, or Abyssinia, into a cultural country. This would be the contribution of the Polish nation to the good of humanity and the Abyssinian people. Each country could thus do something useful, and not just for profit and exploitation, as things were in the old capitalist world.

The progress of the world would be supervised by an international body.

In such an organised world, protected by a global peace pact, we can eventually overcome all our economic and political problems. The pre-war issue of over- 
population is also settled, as we can safely assume that there is still plenty of hitherto uninhabited land, which remains to be claimed by humanity - particularly in Africa, Asia, and Australia. Based on these premises, pursuing our path toward the general improvement of human culture, and thus consumption, leads to an increase in production levels, resulting in the elimination of unemployment worldwide.

Such conditions of peace also attenuate minority issues. Those minorities, whose size and distribution prevent them from constituting condensed socio-economic units, enjoy the rights of free citizens, including the opportunity to use their own language, to form their own cultural organisations, etc. On the other hand, the national minorities living in a defined area, where they make up the majority of the population, may enjoy a certain degree of autonomy, or even constitute an independent republic within the country. We should not exclude the possibility of the minority issues being settled on the grounds of voluntary exchange. However, this should not be achieved via forced displacement and treating people as cattle, but rather by means of mutual agreement.

\section{Implementation}

1. Our position should be made known to the world via official statement and through propaganda. It should contain only general information. Otherwise, it should rather be the subject of skilful, confidential negotiations of our representatives with individual governments. It is clear that our assertiveness in reaching for our goals should vary according the situation.

2. We must establish in each country a political cell with the aim of persuading the local authorities to support our vision of the framework for world peace; we can also contact the existing political parties that would defend our vision or adopt it as an expression of their ideological struggle.

Therefore, we should activate and expand our diplomatic units. Our civilian émigrés should also receive their own propaganda tasks. We can always organise financing for this purpose. Should the British refuse to support us, we will turn to the US government and wherever possible. Debts are not an issue. Considering our overall spending on the war, our expenses are minimal anyway. It should be reminded that after the war, England and the US will issue promissory notes of a completely different nature, compared to which this borrowed cash will amount to merely a fraction. Let us rather focus on this other debt, all while taking as much as cash as possible from wherever possible for our current operational needs. Sources are abundant, we just have to use them wisely. Besides, we can always some shifts in our spending without much damage. For instance, we can reduce the funding of propaganda in Poland by $60 \%$. The radio communiqués from London should suffice, while all other broadcasts could be used for Polish propaganda abroad. We must turn to the English, Turks, Persians, Arabs, Egyptians, Abyssinians, Japanese, Australians, etc.; basically, to all large and small nations. We do not need to write and broadcast that much for Poles; they require solely current news. We could 
reduce by half the publishing of Polish press, all while writing more about Poland in foreign newspapers. After all, Poles do not need to be convinced about the desired shape of our future borders, or that there's a war to win. ${ }^{9}$

Translated by Jakub Perliński

\section{Polish foreign policy and role of the armed forces in geopolitical considerations of Lieutenant Colonel Tadeusz Zakrzewski addressed to Prime Minister Władysław Sikorski Abstract}

In January 1943, Commander-in-chief and Prime Minister of Poland, General Władysław Sikorski, received a memorandum on the objectives of the Polish foreign policy drawn up by Lieutenant Colonel Tadeusz Zakrzewski (1897-1964), former military attaché in Bucharest (1938-1940). The policy was founded on three pillars: the Polish Armed Forces, the Polish populace, and propaganda. He emphasised that Poland would achieve true victory with the consolidation of its independent existence within its pre-war borders in the east, and strategically expanded borders - at the expense of Germany (East Prussia, Opole Silesia) - in the west. Central and Eastern Europe was to be divided between Poland (Union of Central Europe: Poland, Czechoslovakia, Yugoslavia, Greece, and Hungary) and the USSR (Eastern Union: the USSR, Finland, Latvia, Estonia, and Bulgaria). Romania could choose between the two. Peace and security in the world would rely on the cooperation of regional powers and the relations of states supervised by an international organisation. The durability of the post-war order would be ensured by the universal adoption of democracy, the protection of human and minority rights, extensive trade in commodities and raw materials, and the isolation of warmonger states from the international community.

\section{Польская иностранная политика и роль армии в геополитических рассуждениях подполковника Тадеуша Закржевского, обращенных к премьер-министру генералу Владиславу Сикорскому Аннотация}

Бывший военный атташе в Бухаресте (1938-1940), подполковник Тадеуш Закржевский (1897-1964) в январе 1943 г. отправил главнокомандующему и премьер-министру генералу Владиславу Сикорскому докладную записку о целях польской иностранной политики. Ее основой он назначил: польскую армию, отношение страны к немецкому оккупанту и пропаганду польских целей войны. Он подчеркивал, что польской победой в войне должно стать укрепление независимости в довоенных границах на Востоке, расширенных стратегически и экономически за счет Германии (Восточная Пруссия, Опольская Силезия). Центральная и Восточная Европа должны были быть разделены между Польшу (Центральноевропейский Союз - Польша, Чехословакия, Югославия, Греция, Венгрия) и Советский Союз (Восточный Союз - СССР, Финляндия, Латвия, Эстония, Болгария). Румыния могла принадлежать или к Восточному или к Центральному

9 IPMS, no. PRM112/1, T. Zakrzewski, Mój pogląd na politykę zagraniczna Polski i rolę wojska, Jerusalem, 25 January 1943, pp. 47-53. 
Союзу. Мир и мировая безопасность опирались бы на сотрудничество держав и региональные союзы государств в рамках международной организации. Прочность послевоенной системы обеспечили бы: всеобщность демократии, права человека и национальных меньшинств, торговое и сырьевое сотрудничество, изолирование агрессора от международного общества.

\section{Bibliography}

Bułhak H., "Próba czechosłowackich kół wojskowych nawiązania rozmów sojuszniczych z polskim Sztabem Głównym w marcu 1938 r.", Studia z Dziejów ZSRR i Europy Środkowej, 15 (1979).

Dubicki T., Rostworowski S.J., Sanatorzy kontra Sikorszczycy, czyli walka o władzę na uchodźstwie w Rumunii 1939-1940, Warszawa, 1993.

Dubicki T., Wojsko Polskie w Rumunii w latach 1939-1941, Warszawa, 1994.

Dubicki T., Suchcitz A., Oficerowie wywiadu WP i PSZ w latach 1939-1945, vol. 1, Warszawa, 2009.

Dymarski M., Stosunki wewnętrzne wśród polskiego wychodźstwa politycznego i wojskowego we Francji i Wielkiej Brytanii 1939-1945, Wrocław, 1999.

Historia Dyplomacji Polskiej, vol. 4: 1918-1939, ed. P. Łossowski, Warszawa, 1995.

Historia Dyplomacji Polskiej, vol. 5: 1939-1945, ed. W. Michowicz, Warszawa, 1999.

Katelbach T., "Akt pierwszy dramatu”, Zeszyty Historyczne, 7 (1965).

Kowalewski J., "Cykl rumuński”, Zeszyty Historyczne, 6 (1964).

Pobóg-Malinowski W., "Na rumuńskim rozdrożu (fragmenty wspomnień)”, part 3, Kultura, 9-10 (1948).

Pobóg-Malinowski W., Najnowsza historia polityczna Polski (okres 1939-1945), vol. 1, Gdańsk 1990.

Poniński A., "Wrzesień 1939 r. w Rumunii”, Zeszyty Historyczne, 6 (1964).

Dariusz Miszewski, Ph.D., historian, graduate of the University of Wrocław, assistant professor at the Section of International Relations of the Institute of Political Science of the University of Zielona Góra (1999-2013); since 2016 assistant professor at the Faculty of National Security of the War Studies University in Warsaw. He specialises in Polish-Czechoslovak and Polish-Czech relations in the $20^{\text {th }}$ and $21^{\text {st }}$ century, national minorities in Central Europe, and Polish political thought in the $20^{\text {th }}$ century (d.miszewski@op.pl). 